\title{
A geological munal
}

\section{H.T. De la Beche Esq. F.R.S. F.G.S.}

To cite this article: H.T. De la Beche Esq. F.R.S. F.G.S. (1832) A geological munal, Philosophical Magazine Series 2, 11:61, 46-53, DOI: 10.1080/14786443208647669

To link to this article: http://dx.doi.org/10.1080/14786443208647669

册 Published online: 25 Jun 2009.

Submit your article to this journal $x$

LII Article views: 2

Q View related articles $₫$ 
by which we have another check on all preceding calculations. The double areal velocity really taking place in the true ellipsis $k^{\prime}$, the time of revolution $U$, and the mean motion in degree $\mu^{\prime}$ may be derived from these equations:

$$
\begin{aligned}
& k^{\prime}=k \sec i^{\prime}, \\
& \mu^{\prime}=\frac{k^{\prime}}{2 a^{\prime} b^{\prime} \pi} 360^{\circ}=\frac{k}{2 a b \pi} 360^{\circ}, \\
& \mathrm{U}=\frac{2 a^{\prime} b^{\prime} \pi}{k^{\prime}}=\frac{2 a b \pi}{k},
\end{aligned}
$$

in which the unit of time is that in which the observations have been recorded, and the unit of space the second of an arc by which the distances have been measured.

[To be continued.]

\section{Notices respecting Nerw Books.}

A Geological Manual. By H. T. DE LA Beche, Esq. F.R.S. F.G.S. \&c.

$I^{\mathrm{T}}$ $\mathrm{T}$ is not long since Mr. De la Beche presented to the scientific world a useful and instructive collection of "Sections and Views illustrative of Geological Phænomena *." 'To this publication he has now added a more systematic and important volume, entitled, "A Geological Manual," a work of first-rate importance in the science to which it relates, and which must henceforth take its place in the library of every student in geology.

The author approaches his subject eminently qualified for the task he has undertaken, having devoted many years of his life most assiduously to this engaging pursuit. His information on English geclogy is founded on long-continued personal examination of the strata of this country, and on a fumiliar acquaintance with all that has been written respecting them : to this he adds an extensive knowledge of European geology, collected during many tours on the Continent, and from copious reading. He has further extended his observations to tropical regions, by a visit to the West Indies.

$A$ vast and faithful accumulation of facts has resulted from the industrious use of such rare and precious opportunities. These have been systematically arranged in the work before us, and upon them the author has been cautious to found such conclusions only as he thinks to be warranted by the premises before him. We consider the additions he has thus made to our stock of geological knowledge to be a very important step in our advancement towards a true theory of the earth.

The author commences his work with an account of the figure and density of the earth, the superficial distribution of land and water, the saltness and specific gravity of the sea, and the temperature of the

* See Phil. Mag. and Annals, N.S. vol. ix. p. 131.

earth, 
aarth, as well as that of springs, of seas and lakes, and of the atmosphere; and after noticing the various forms of valleys, and the obvious changes now produced on the surface of our planet, he proceeds to a classitication of rocks, differing but little from that published by him some months since in this Journal*. In a tabular form he shows its relations to the improved Wernerian classification, and to the classifications of Conybeare, Omalius d'Halloy, and Brongniart. 'This classification, which exhibits the rocks in the descending order, forms the base on which the arrangement of the remaining part of the volume is founded, and is chiefly characterized by the division of roeks into Stratified and Unstratified; the former being divided into Fossiliferous, or those which contain organic remains; and Non-fossiliferous, or those in which no animal or vegetable exuviæ have ever yet been detected. The fossiliferous deposits are subdivided into groups, the first of which is termed Modern; and under this head the author has treated of the various causes which produce alterations on the actual surface of the globe. We here find an account of the degradation of land, the delivery of detritus into the sea, the action of the sea on coasts, shingle beaches, sandy beaches, tides, currents, the transporting powers of tides and currents, active volcanos, extinct volcanos, mineral volcanic products, earthquakes, gaseous exhalations, deposits from springs, coral reefs and islands, submarine forests, raised beaches and masses of shells, and finally a notice of the arganic remains that may be entombed in deposits now in process of formation.

In treating on the above subjects the author appears desirous of stating fairly the amount of that change which may be produced on the surface of our planet by the causes usually termed actual; so that when the phænomena of a more ancient date are presented to the attention of the reader, he might be enabled to institute a comparison between the effects which we daily witness and those which have been produced at more remote periods in the history of the world.

We subjoin a few extracts to show the author's mode of treating his subject, as far as can be done without the aid of the numerous illustrative sections contained in this volume.-Speaking of the often supposed case of the bursting of a lake, and the consequent deluge that it has been imagined such a catastrophe would produce, he $o \vec{b}$ serves :

"The waters of a lake can only be suddenly let out and produce a debacle when the hard barrier separating it from the land at a lower level presents a perpendicular face to the whole depth of the lake, which, even then, must be suddenly thrown down in its whole height to produce the effect required. Such rocky barriers must be exceedingly rare; and it must be still more rare that where they existed they were not cut down, to a certain extent, by degrees. The common character of lakes, as respects the inclination from their bottoms to the discharging outlet, varies materially; but in general the slope is very gradual, particularly in lakes of considerable magnitude."

A diagram illustrates the manner in which the lake Erie would be

* Phil. Mag. and Annals, N.S. vol. vi. p. 440. 
drained if the Falls of Niagara should retreat to it ; and it is shown that, far from producing a deluge or debacle, as has been often supposed, the result would be a drainage, which, though more rapid at certain intervals, would still in the main be gradual, finally leaving a river flowing through the bed of the discharged lake.

Respecting the embouchures of rivers, it is observed, that "if the mouths of rivers be tidal, the river detritus is committed to the charge of the estuary tides, and is dealt with according to the laws by which these are governed. If they be tideless, the whole mass of transported matter will be propelled without check into the seas at the embouchures. Between the extremes of great resistance and non-resistance the variations are so great, and depend so much on local circumstances, as to be of exceedingly difficult classification. The principal variations are produced by the difference in the volume of the discharging rivers, their velocities, and the quantity and quality of the substances they may transport. As a general fact, however, it may be stated that rivers tend to form deltas in tideless, or nearly tideless, seas; or where they can overcome the resistance of tides, currents, and the destructive action of the breakers; thus increasing the land by their deposit, and splitting into severa! channels, the superficial increase being in proportion to the depth of water into which the rivers discharge themselves."

"In calculations of the advance of deltas, care has not always been taken to show the general depth of water into which they may have been protruded; so that a less quantity of transported detritus might expose a larger surface when thrown on a shallow bottom, than a larger quantity in deeper water."

The author observes, under the head of Beaches, that " the action of the waves round coasts tends to disturb the bottom at certain depths, and to move the shells, sands, and other substances of which this bottom is composed, towards the land. The exact depth to which the moving action of waves extends, seems never to have been very accurately estimated : indeed, when we consider that the power of the wave is continually varying, such an estimate becomes exceedingly difficult. Ninety feet, or fifteen fathoms, has been sometimes considered as the limit, in depth, to which this disturbing power extends; but this requires confrmation. Around coasts and on shores which do not much exceed ten or twelve fathoms, the action of the waves is very apparent in the discoloration of the water during heavy gales. This turbid character of the sea is due to the moving power of the waves on the bottom, and becomes more marked as the water becomes more shallow, either in approaching the land or over shoals. The transporting power of the waves will therefore be in proportion to the depth of water beneath them, the transport being greatest in the shallowest places. The waves will tend to throw substances on coasts, because the off-shore wind produces smaller waves than the wind blowing upon the land. On shoals distant from the land the effect will be somewhat different, and the piling or propelling power will be greatest on the side of the prevalent or more violent winds. Shoals will be also liable to shift, as the turbid waters on the crown of a 
shoal will be forced over on the lee side. Accordingly we do find that shoals shift, more particularly when near the surface, unless there be an equal counteracting effect in a current or tide."

Mr. De la Beche has collected scattered notices respecting the various principal currents of the globe, and endeavours to show that the hypothesis of their being sufficient to transport the detritus of the land over the depths of the ocean, and from Europe to America, is not founded on those facts which have been brought to light respecting currents. He observes :

"In estimating the transporting power of currents, we should consider the causes which produce them, and the nature of the fluid in which they are produced. The motion of the earth, although it would seem to give a certain general movement to the waters of our globe, would not appear capable, taken by itself, to produce currents of geological importance. 'The great cause of ocean-currents would seem to be prevalent winds; and accordingly we find that in the equatorial regions of the world, over which the more or less easterly winds, commonly called the trade winds, prevail, there is a tendency of the waters to flow westward in the Pacific Ocean, in the Atlantic, and in those parts of the Indian Seas free from the monsoons. That the winds are the great cause of ocean-currents, is a fact sufficiently proved by the velocity and direction of such currents in the Indian and Chinese seas, varying with the force and direction of the monsoons.

"The winds being, generally speaking, the cause of the great oceancurrents, and effects being only in proportion to their causes, the streams of water thus produced will not extend deeper than the propelling power of the winds can be felt. Now, as the ocean varies in density according to its depth, the cause sufficient to move waters on the surface, and to certain depths beneath it, will constantly meet with opposition at an increasing ratio, until, finally, the moving power and the resistance being equal, no effect whatever is produced; and all water beneath a certain depth would be, as far as respects surface causes, immovable, and consequently would have no transporting power.

"Hence it would appear that the transporting power of currents will depend on the depth of the sea, all other things being equal; and that the smaller the depth the greater the transporting power. Consequently, coasts are the situations where we may look for this power."

Throughout the work there are copious lists, derived from the best authorities, of the various organic remains discovered in each group of rocks, not only in the British Islands, but in Europe generally, and even in some cases extending to India and North America. These are for the most part accompanied by remarks relating to each collection of such exuviæ. While noticing the remains of vegetables and animals which may be enveloped in the deposits formed during the present order of things, Mr. De la Beche observes :

"These will necessarily consist of existing animals, but may also include some no longer found in a living state. Man not only greatly modifies the present surface of the land by destroying tracts of forests,

N.S. Vol. 11. No. 61. Jan. 1832. 
preventing the inundation of low countries, turning torrents, and directing the surface-water through innumerable channels to satisfy his own wants and conveniences; but he also drives all animals before him which do not suit his purposes, thus circumscribing the domain of those which are not useful to him, while he covers the country with those that are, and which never could exist in such numbers but for his care and protection. Consequently all terrestrial remains would correspond with the increasing power of man, and therefore a very different suite of such remains would be now entombed than when his power was more limited. Over the inhabitants of the waters he would exercise little controul, excepting in rivers, small lakes, and around some coasts.

" One very material difference would be effected in the quantity of trees and shrubs transported to the sea, more particularly in the temperate and colder regions, where man requires wood, not only for the purposes of various constructions, but also for fuel. We see in the delta of the Mississippi what an abunlance of wood is now transported there by the river, but which will daily diminish as man converts the forests whence it is derived into pastures and corn-fields.

"The gigantic animal Cervus giganteus, commonly known as the Irish Elk, was once imagined to have existed only at an epoch anterior to man, but it is now considered that he was coexistent with him; although this by no means proves that he did not live upon the earth previous also to him, as seems to have been the case. We have no great certainty when the Mastodons of North America ceased to exist; it is commonly supposed that they became extinct previous to the commencement of the modern group, but of this we have no good proof. The same may be said of some other animals.

"The Dodo seems to afford us an example of the extinction of an animal in comparatively recent times; for it is now almost certain that this curious bird existed on the Isle of Mauritius during the voyages of the early navigators to the East Indies. The relative antiquity, therefore, of animals whose remains are only now found entombed, must not be too hastily inferred. The bone of the wolf is that of an extinct animal, as far as the British Islands are concerned."

Our limits prevent us from noticing the various remarks on the organic character of each group of rocks, further than by extracting the author's observations on the oolitic series, and on what he terms the lowest fossiliferous group.

"It has been above remarked that the surface on which the oolitic group was deposited, was probably at very various depths beneath that of the sea, and that even during the deposit itself, the sea varied in depth over the same point, in consequence of movements in the land. The nature of the organic remains also apparently points to the proximity of dry land in some places, while it may have been comparatively remote in others. It does not seem unphilosophical to infer that the bays, creeks, estuaries, rivers, and dry land were tenanted by animals, each fitted to the situations where it could feed, breed, and defend itself from the attacks of its enemies. That strange reptile the Ichthyosaurus (one species of which, I. platyodon, was of a large size, the 
jaws being strong, and occasionally cight feet in length) may from its form have braved the waves of the sen, dashing through them as the porpess now does; but the Plesiosaurus, at least the species with the long neck ( $\boldsymbol{H}$. dolichodeirus), would be better suited to have fished in shallow creeks and bays, defended from heavy breakers. 'The crocodiles were probably, as their congeners of the present day are, lovers of rivers and estuaries, and like them destructive and voracious. Of the various reptiles of this period, the Ichthyosaurus, particularly the I. platyodon, seems to have been best suited to rule in the waters, its powerful and capacious jaws being an overmatch for those of the crocodiles and Plesiosauri. Thanks to Professor Buckland we are now acquainted with some of the food upon which these creatures lived; their fossil fæces, named coprolites, having afforded evidence, not only that they devoured fish, but each other, the smaller becoming the prey of the larger, as is abundantly testified by the undigested remains of vertebræ and other bones contained in the coprolites. Amid such voracity, it seems wonderful that so many escaped to be imbedded in rocks, and after the lapse of ages on ages to tell the tale of their existence as former in habitants of our planet. And strange inhabitants they undoubtedly were; for, as Cuvier says, the Ichthyosaurus has the snout of a dolphin, the teeth of a crocodile, the head and sternum of a lizard, the extremities of cetacea, (being however four in number, ) and the vertebræ of fish; while the Plesiosaurus has, with the same cetaceous extremities, the head of a lizard, and a neck resembling the body of a serpent.

"That the Pterodactyles should be scarce fossils is what we should expect, for the circumstances favourable to their preservation must have been exceedingly rare. Even supposing that they dashed out to sea in pursuit of their insect prey, there must have been a combination of fortunate accidents to have prevented the Pterodactyles and their intended prey from being devoured by the fish and other inhabitants of the sea, among the exuviæ of which their lemains are now detected.

"It is curious, and seems to establish a connection between the insects and the Pterodactyles, that in the spot (Solenhofen) where the remains of the latter are most abundant, the greatest quantity of fossil insects yet noticed in the oolitic group have been detected. At Stonesfield also, where the remains of insects are stated to have been discovered, the exuviæ of Pterodactyles, according to Professor Buckland, are also observed. Not so however with the Pierodactyles of Lyme Regis, whose remains are mixed with those of Ichthyosauri and other marine animals, where insects have not yet been discovered. But when we consider the abundant exuviæ of Plesiosauri, perhaps we may not err greatly in considering dry land [to have been] not very far distant from the spot where we now find their bones entombed. Be the case as it may, a Pterodactyle in a sea amid Ichthyosauri and other voracious creatures must have had but a slight chance of escape, and geologists should be grateful that any combination of circumstances should have so far prevailed as to permit the preservation of even a $\mathrm{H}_{2}$ single 
single individual, to show us the strange terrestrial creatures that then existed."

Respecting the possible character of the animals which first appeared on the surface of the globe, the author observes:

"Whatever the kind of animal life may have been which first appeared on the surface of our planet, we may be certain that it was consistent with the wisdom and design which has always prevailed throughout nature, and that each creature was peculiarly adapted to that situation destined to be occupied by it. Bearing therefore in mind this general adaptation of animals to the circunstances under which they are placed, we may be led so far to speculate at this early condition of life as to inquire what kind of creatures, judging from the general character of those known to us, might flourish at a period when there might have been a comparative difficulty in procuring carbonate of lime for their solid parts. It will be obvious that fleshy and gelatinous creatures, such as Meduse and other animals of the like kind, might have abounded, as far as regards a comparative scarcity of this substance. Hence it would be possible to have the seas swarming with these and similar animals, while testaceous creatures and others with solid parts were rare.

"'These remarks are merely intended to show that the scarcity of organic remains observed in the lowest fossiliferous deposits by no means proves a scarcity of animal life at the same period, though from it we may infer that testaceous and other animals with solid parts were not abundant. Mere fleshy creatures may have existed in myriads without a trace of them having been transmitted to us. In proof of this, if any were requisite, we may inquire what portion of those myriads of fleshy animals which now swarm in some seas could be transmitted, as organic remains, to future ages."

Having described the inferior stratified rocks, such as gneiss, mica slate, \&c., Mr. De la Beche proceeds to the consideration of the unstratified rocks, such as granite, the trap-rocks, \&c., and remarks respecting the latter, that " if we regard these various igneous products as a mass of matter which has successively and during the lapse of all that time coinprehended between the earliest formation of the stratified rocks and the present day, been ejected from the interior of the earth, we shall be struck with certain differences of these rocks on the great scale, which have led to their practical arrangement under the heads of granitic, trappean, serpentinous, and volcanic products, as above noticed. The two former and the last occur most abundantly, whilst the third is comparatively more scarce, though sufficiently common in nature. As yet we are unacquainted with the conditions necessary for the production of these different compounds, and it would be a highly interesting inquiry, and one well worthy of the attention of the chemist, to ascertain as nearly as may be the essential average differences which may exist as to the ultimate elementary substances constituting the rocks of this nature, thus approaching towards a knowledge of the possible circumstances which may have determined such substances to arrange themselves in one manner rather than in another. Possibly the quantity and proportion 
of the elementary substances might not vary so much as we might, from the general mineral character alone, be led to expect; but at first sight we may imagine that silica predominated more in the granitic rocks than in the others, while magnesia abounded in those parts of the earth which vomited forth the serpentinous deposits. It is however obviously premature to speculate upon that which can only be learned through the medium of careful and exact investigation; and the subject is only introduced for the purpose of promoting inquiry, and the possibility of attracting the attention of those chemists who may be induced to enter on the hitherto little explored though vast field of chemical geology."

The author concludes his volume with dissertations on the mineralogical differences in contemporaneous rocks, either original, or resulting from alteration after deposition; on the elevation of mountains (consisting principally of abstracts from friendly communications by $M$. Elie de Beaumont on this subject); and on the occurrence of metals in rocks; and by an Appendix containing, among other things, observations on geological maps and sections, and tables for calculating heights by the barometer.

An Account of Inventions and Improvements in Surgical Instruments, made by J. Werss, 62 Strand; with a Selection of Cases wherein they have been successfully employed. 8vo. pp. 200.

It does not always happen that the benefits accruing to the community from the exertions of an individual can be understood or appreciated from a written statement; and it not unfrequently occurs that inventions are silently and slowly producing the most advantageous results, while those to whom the world is indebted for them are unknown or neglected. This is in a great measure unavoidable; it is the common chance of blanks and prizes in the lottery of life, and at the present day especially may depend much upon the profligate system of outrageous puffing which makes success depend less upon merit than upon eftrontery.

We make these observations without any particular reference to the author of the work before us. The volume fell into our hands accidentally, and we felt it would be as well an act of justice to the writer as of duty to the public, to direct their attention to it. Surgery may now be regarded as a positive science; and, without detracting in the least from the skill of the performer, we consider that no trifling merit is due to the inventor or improver or fabricator of an instrument by which the risk of a dangerous operation is diminished, or alleviation afforded in any case in which relief had been previously sought in vain. For such purposes ingenuity of contrivance is not less necessary than mechanical skill; and when the mitigation of the ills which flesh is heir to is the object in view, it matters not, for the benefit of mankind, whether the individual pursuing it draws exclusively upon the resources of his own mind, or adopts the suggestions of others. With these sentiments we notice the work of which the title is prefixed to this article. It is the production of a plain man detailing what he 